\title{
Maria Bárbara Madureira e as Cartas Baianas: uma vivência feminina no ínicio do século XIX
}

\author{
Etelvina Maria de Castro TRINDADE*
}

\begin{abstract}
RESUMO
Este trabalho procura recuperar aspectos do cotidiano da Província da Bahia e as relações familiares e de gênero em uma família proprietária de engenho, às vésperas da independência do Brasil. Tem como figura central a portuguesa Maria Bárbara Garcês Pinto de Madureira cujas cartas dirigidas ao marido ausente, em missão nas Cortes portuguesas, dão subsídios para que seja traçada uma vivência feminina e feita uma reflexão sobre as condições de determinadas mulheres naquele espaço e período.
\end{abstract}

Palavras-chave: história do Brasil, gênero, mulheres letradas, biografia.

\begin{abstract}
This work looks to recover some aspects of the day by day of Bahia Province and the family relations and gender in a family of sugar plantation and mill owners, on the turn of Brasil's Independence. The central figure, a portuguese named Maria Bárbara Garcês Pinto de Madureira, whose letters to her absent husband, in a mission to the protuguese Assembly, subsidise the confection of a feminine profile and understanding the conditions of a group of womens at that time and space.
\end{abstract}

Key-words: brazilian History, gender, educated women, biography.

* Professora Adjunta da Universidade Federal do Paraná. 


\section{Introdução}

A familiaridade que o historiador adquire com o constante processo de busca e manipulação das fontes necessárias ao seu métier faz dele um apreciador nato de uma tarefa como a que foi realizada pelo autor do livro Cartas Baianas. ${ }^{1}$ Ao recolher e classificar uma coletânea de documentos muito rica para o estudo da História do Brasil e de Portugal na fase conturbada de transição entre o período colonial e início da independência, o escritor português Antônio D'Oliveira Pinto da França trouxe uma importante contribuição aos estudiosos da história social e cultural e, mais recentemente dos estudos de gênero.

Reunidas por esse descendente longínquo de D. Maria Bárbara Garcês Pinto de Madureira, as cartas trocadas com Luís Paulino têm autores diversos, centrando-se, no entanto, na ativa correspondência enviada por Maria Bárbara ao marido ausente no exercício da função de representante brasileiro nas Cortes de Lisboa, quando da elaboração da Constituição do Reino Unido, em 1821 e 1822.

Mas, o ponto alto dessa coleção não reside em seu puro aspecto documental e sim no tipo de subsídio que ela oferece. Ou seja, de destacar uma correspondência que possibilita "rastrear, identificar, analisar o modo como, através das cartas enquanto prática escrita (...), uma realidade social é construída, pensada, dada a ler e materializada (...)."2 Mais especificamente, permite uma aproximação íntima com um personagem feminino que, ao relatar fatos de seu cotidiano, fornece as coordenadas para a análise, não apenas de sua vivência pessoal, como da conjuntura sociopolítica da época e do papel da mulher naquela realidade.

Como os diários, as cartas fazem parte da literatura feminina que se encontra atrelada ao processo de inserção das mulheres nas aprendizagens elementares à expressão escrita de si próprias, (como a alfabetização e a leitura), ocorridas no final do século XVIII e no decorrer do XIX. Uma época

1 FRANÇA, A. O. P. da. Cartas Baianas. 1821-1824. São Paulo: Companhia Editora Nacional, 1980 .

2 CAMARGO, M. R. Cartas adolescentes. Uma leitura e modos de ser... In: Refúgio do eu: educação, história e escritos autobiográficos. Florianópolis: Mulheres, 2000. p. 205. 
em que um grande número delas começou a desenvolver os hábitos de leitura e a conhecer o que havia sido escrito a seu respeito nas publicações laicas e religiosas. Daí começarem a refletir sobre si mesmas e a buscar os modos de expressão que estavam a seu alcance, tais como os diários, as cartas, e até artigos e livros escritos sob pseudônimo. ${ }^{3}$

Da mesma maneira que na Europa e América do Norte, a escrita feminina no Brasil também encontrou obstáculos que, aqui, provinham de uma mentalidade atrelada a valores ainda arcaicos, em que os pais de família restringiam o aprendizado das filhas em nome da moral e dos costumes. Isso não impediu que algumas escritoras brasileiras tivessem visibilidade, desde o início dos oitocentos, como Nísia Floresta e Ana de Barandas. ${ }^{4}$

Sem oportunidade de empreender carreira literária, ou talvez sem vocação para tal, Maria Bárbara também é parte, mesmo sendo portuguesa, do universo letrado feminino que começava a se delinear no Brasil nas primeiras décadas do século XIX. E foi na sua província de adoção, a Bahia, que ela teve oportunidade de exercer funções que não eram propriamente femininas e expressar-se através da pena deixando como legado, o relato de suas experiências.

\section{Bahia: início do século XIX}

A reconstituição de um determinado contexto histórico e social permite, não só a compreensão de uma realidade específica, mas preencher as lacunas que podem cercar um personagem estudado. ${ }^{5}$ Assim, a compreensão da visão do mundo em que viveu determinado indivíduo pode facilitar o conhecimento de como ele conduziu os acontecimentos

3 HOOK-DE-MARLE, M. C. Ler e escrever na Alemanha. In: História das mulheres: o século XIX. Porto: Afrontamento, 1991. v. 4, p. 171-197.

4 TELLES, N. Escritora, escritos, escrituras, In: DEL PRIORE, M. (Org.). História das mulheres no Brasil. São Paulo: Contexto, 1997. p. 401-442.

5 DIAS, C. G. P. Um olhar sobre o livro Nas margens de Natalie Zemon Davis: em busca de uma reflexão a partir do gênero biográfico. Histórica, Porto Alegre, n. 5. p. 103-110. 2001. 
que pontuaram sua vida tentando convertê-los em seu favor. O somatório de indivíduo e contexto torna, então, possível destacar o papel determinante da individualidade, sem renunciar totalmente à generalização. ${ }^{6}$ É isso o que se pretende ao tentar uma reconstituição do tempo e espaço onde Maria Bárbara viveu e onde ocorreram os eventos que acompanharam a redação das Cartas Baianas.

Situam-se elas num contexto que envolve, ao mesmo tempo, os primeiros ensaios de uma posição brasileira a favor da independência e uma reação portuguesa totalmente oposta a essa pretensão; uma situação específica, a da Bahia nessa conjuntura, e uma situação familiar, a de Luis Paulino D' Oliveira Pinto da França, sua mulher e filhos, face a esses eventos.

No caso do Brasil, a partida de D. João VI para Portugal em virtude da Revolução de 1820, no Porto, e a conseqüente ascensão de D. Pedro a príncipe regente do Reino Unido, desencadearam uma reação de grupos contrários à política de recolonização intentada pelas Cortes Portuguesas. Para tanto, uniram-se aos interesses de diversas camadas sociais, desde grandes proprietários de terra, beneficiários de uma política econômica autônoma em relação a Portugal, aos grupos urbanos de orientação liberal e democrática. O movimento ganhou corpo com incentivo de intelectuais e da imprensa, conquanto o grosso da população, sobretudo os habitantes da zona rural, se mantivesse alheio ao processo. ${ }^{7}$

Em Portugal, a situação era diversa. Após a convocação das Cortes e o juramento antecipado da nova Constituição por D. João VI, a estratégia desenvolvida em relação ao Brasil era de retomar o controle econômico e administrativo do país, reconduzindo-o à situação de colônia, através de várias medidas tributárias e tentativas de reforço do poder político e militar da metrópole.

Os choques entre a posição cada vez mais separatista das elites brasileiras e a atitude progressivamente centralizadora de Portugal, acabaram por concentrar-se no questionamento ao exercício da autoridade exercida pelo príncipe D. Pedro, o que facilitou, finalmente, uma tomada de decisão de caráter independizante.

6 BENSA, A. Da microhistória a uma antropologia crítica. In: REVEL, J. (Org). Jogos de escalas. A experiência da microanálise. São Paulo: Fundação Getúlio Vargas, 1998. p. 62.

7 Textos clássicos sobre este período encontram-se em: COSTA, E. V. da. Da Monarquia à República: momentos decisivos. São Paulo: Brasiliense, 1985. 
Configurada a independência, o período seguinte foi marcado pelo desajuste entre as posições das províncias, algumas delas contrárias ao desligamento da metrópole. Uma das que apresentaram situação mais tumultuada, antes e depois da independência, foi a província da Bahia, onde havia grande número de comerciantes, sobretudo portugueses que, como credores dos agricultores brasileiros, só teriam a perder com a independência; a eles se uniam os militares, cujo comandante, Madeira de Melo, era fiel aos interesses lusos. Os choques entre brasileiros e portugueses ocorridos durante todo o processo, sofreram um agravamento, chegando ao conflito armado até que, em 1823, a derrota lusitana frente ao almirante Cochrane e a acomodação de proprietários de terra e comerciantes diante do perigo de uma insurreição de escravos, levou à pacificação geral.

Foi na Bahia, e nessa conjuntura, que se desenrolou o drama vivido pelos personagens das Cartas Baianas. Luís Paulino Pinto da França, sujeito oculto dos acontecimentos tinha interesses e atividades que mostram uma personalidade refinada, um homem, ao mesmo tempo, de cultura e de ação. Nascido na Bahia, ocupou vários cargos na política, na diplomacia e no exército. Apesar de escritor e poeta, não desprezava os interesses econômicos, sendo senhor de engenho em Aramaré, no Recôncavo Baiano. Ligado a Portugal por fortes laços de família e pela participação nas lutas napoleônicas, foi muito prestigiado pelo rei D. João VI, a quem serviu com dedicação. ${ }^{8}$

Os acontecimentos que motivaram a redação das cartas dirigidas a Luís Paulino por seus familiares estão relacionados à já mencionada convocação das Cortes Constituintes em Portugal, ocasião em que o Brasil enviou cinqüenta deputados eleitos como representantes de seus interesses naquela reunião. Luís Paulino, escolhido por sua província, seguiu com a delegação. Os trabalhos da Constituinte foram, no entanto, tumultuados, sobretudo pelas divergências entre brasileiros e portugueses a respeito da posição reservada ao Brasil na nova organização política e econômica do Reino. E, apesar da atitude francamente conciliatória de uma parte de brasileiros como Araújo Lima, José de Alencar e o próprio

8 As informações sobre Luís Paulino e sua família encontram-se no prefácio do livro de Pinto da França já referido. 
Luís Paulino, as posições do grupo exaltado, liderado por Cipriano Barata, levaram a um rompimento definitivo e à retirada dos representantes brasileiros da Assembléia.

O fato de Luís Paulino ter jurado e assinado, juntamente com a ala moderada, a nova Constituição considerada desfavorável ao Brasil, não seria tão grave, se a isso ele não acrescentasse uma longa permanência em Portugal após a retirada de seus colegas, exercendo inclusive cargos de confiança no exército português. Daí só retornaria ao Brasil em 1823, em missão de conciliação, como enviado de D. João VI. Repelido duramente por seus conterrâneos e pelo Imperador, e não podendo desembarcar do navio, faleceu no mar quando retornava a Portugal.

As atitudes de Luís Paulino - veementemente repudiadas por inimigos, colegas e alguns parentes - podem justificar-se, ora pelos laços de fidelidade e gratidão que o uniam a D. João VI, ora pela posição política tradicionalmente de centro adotada pela família Pinto da França; ou ainda pela dupla vertente brasileira e lusitana que alimentava, na família, uma atitude conciliatória, mercê da dificuldade em optar por um dos dois países. De qualquer maneira, a ausência de documentação sobre o assunto, em virtude do extravio das respostas que Luís Paulino teria enviado aos seus, impossibilitam atingir-se resultados conclusivos a respeito. Além disso, as missivas enviadas pela família, achavam-se mais centradas nos problemas locais do que nas vicissitudes de Luís Paulino em Portugal. Essa é, no entanto, uma questão menor para os fins desse estudo, face à possibilidade de explorar-se outros ângulos de análise, sobretudo as cartas de Maria Bárbára, das quais se pode depreender a experiência de uma mulher que chamou para si a difícil administração dos bens familiares na ausência do marido, embora pudesse delegar essa função a seus filhos, homens e adultos.

\section{O personagem Maria Bárbara}

Após muito tempo de atenção aos destinos coletivos, pode-se afimar que o indivíduo está novamente presente nas reflexões dos historiadores. Nesse processo, o gênero biográfico vem ganhando espaços nos 
estudos voltados a um movimento de restauração do papel dos indivíduos na construção dos laços sociais, ${ }^{9}$ trazendo à tona a temporalidade onde se desenrolam as vidas humanas, sem descartar a influência do contexto maior em que os sujeitos estão inseridos. ${ }^{10}$ Por esse motivo, "a história pessoal não tenta substituir outras formas de história (...), nem é um substituto para o estudo do comportamento coletivo, instituições e comunidades, mas sim, seu complemento." ${ }^{11}$ Diferentemente da biografia tradicional que priorizava demasiadamente o indivíduo, fazendo a história pessoal dos grandes vultos, essa nova abordagem busca hoje "pensar a articulação entre as trajetórias individuais examinadas e os contextos nos quais elas se realizaram, como via de mão dupla."12 Nesse caso, a biografia pode desenvolver, além das interpretações sobre a época em viveu certo personagem, outras pespectivas que mostrem sua experências pessoais, e - por que não? passagens pitorescas de sua vida e, até mesmo, suas emoções. ${ }^{13}$

Dentre os diversos ângulos em que podem ser analisadas as vidas e as relações familiares e de gênero na família de Luiz Paulino, o que oferece maior riqueza de análise é o que se refere à Maria Bárbara, quer em seu aspecto individual, quer em sua posição como elemento feminino dentro de uma sociedade que ainda mantinha uma visão de mundo colonial e patriarcalista. Nessa conjuntura estavam presentes atitudes misóginas que relegavam as mulheres a uma condição de minoridade face ao contingente masculino da população.

Investigando-se, inicialmente, sua pessoa, verifica-se ser ela de origem portuguesa, natural de Penafiel, no interior norte de Portugal, nascida em algum ano da década de 1770-1780. Proveniente de uma família da aristocracia rural é de se admirar o fato de ser letrada numa época e numa sociedade em que as mulheres nascidas no campo permaneciam, na maior

9 CHARTIER, R. A História hoje: dúvidas, desafios e propostas. Estudos Históricos, Rio de Janeiro, p. 97-113, 1994.

10 BENSA, op. cit., p. 62-63.

11 ZELDIN, T. História pessoal e história das emoções. História: Questões \& Debates, Curitiba, ano12, n. 22/23, p. 33, jun./dez. 1991.

12 SCHMIDT, B. B. Construindo biografias... historiadores e jornalistas: aproximações e afastamentos. Estudos Históricos, Rio de Janeiro, p. 15, 1997.

13 Ibid., p. 37. 
parte dos casos, alheias à instrução. Duas cartas de sua mãe, incluídas na coletânea, levam, no entanto, à reflexão de que a família de Maria Bárbara deveria ter uma boa posição social e cultural e até certos foros de nobreza, circunstância que beneficiava suas representantes do sexo feminino.

Antonio Pinto da França, no prefácio de sua obra, descreve Maria Bárbara como mulher opulenta, vigorosa e ruiva, conquanto bela e, para ilustrar esse retrato, reproduz a descrição que dela fez o viajante italiano Patroni, quando a ouviu cantar ao piano, em 1829, num engenho da Bahia:

A doçura de sua voz encantou os meus sentidos, e fez em mim a mesma impressão que Vênus fizera no Pai dos deuses, quando as lácteas tetas the tremiam no concílio celeste, congregado para decidir da sorte dos lusitanos nos mares da India. ${ }^{14}$

Aos dotes físicos acrescentavam-se os intelectuais. Como já se observou, mulheres letradas pareciam ser habituais na família de Maria Bárbara; suas filhas também o eram, inclusive a caçula que, aos sete anos, já escrevia algumas linhas ao pai. E às letras se acrescentava a cultura; como bem lembra Antonio Pinto da França, Maria Bárbara citava Camões reproduzia máximas latinas e manipulava os conceitos românticos de pátria, nação, independência e poder constitucional. ${ }^{15}$ Por detrás de tudo isso, percebe-se ainda os traços de uma inteligência viva, alerta e organizada, patente em seu estilo claro e lógico.

Mas não são apenas os dons intelectuais de Maria Bárbara que a transparência das cartas deixa entrever; é todo seu temperamento que aí se evidencia. Sente-se em seus escritos o traço passional, no ímpeto com que expõe seu amor ao marido, ou o ressentimento a seus inimigos: "Adeus, adorado Luís, minha consolação e vida. Adeus, sou toda tua," ${ }^{16}$ despede-se numa missiva em que lamentava o incidente em que Luís Paulino fora agredido por Cipriano Barata, a quem ela se refere como "homem traidor e covarde... assassino infame!"17 A manifestação de seus sentimentos utiliza as

14 FRANÇA, op. cit., p. XIV, Prefácio.

15 Ibid., p. XV.

16 Carta de 28 de junho de 1822.

17 Id. 
palavras e expressões adequadamente colocadas para transmitir ao destinatário toda força de suas emoções. Estreitamente ligada a esses traços de caráter, evidencia-se uma personalidade decidida, independente e dominadora. Ainda a respeito de um inimigo do marido diz: "Eu nunca vi tão negra traição! Meu filho, eu tenho ânimo de beber-lhe o sangue." ${ }^{18} \mathrm{E}$, mais adiante, lamentando a impossibilidade de deixar o engenho, afirma com segurança: “...se não tinha ficado, o engenho Aramaré dentro em pouco 'era campo onde foi Tróia'."'19

Toda essa segurança vinha a par com uma atitude afinada com os valores de seu tempo, em que a instituição familiar era mais importante que o bem-estar individual. Isso não impedia, todavia, que aflorassem, muitas vezes, em seus escritos, preocupações bem corriqueiras com sua própria pessoa. Chama atenção, o fato dos infortúnios do marido serem tratados de forma apressada, apesar de veemente, enquanto ela passava rapidamente a falar de seus problemas familiares, de saúde, políticos e financeiros, com riqueza de detalhes. Em carta de 1823, Maria Bárbara comentava que a letra do marido estava trêmula, dizendo saber do estado em que ele se encontrava. (Luís Paulino morreria tuberculoso pouco depois). Mas, em seguida, afirmava estar "em estado digno de lástima," ao saber das injustiças que ele sofria; lamentava não poder tomar os banhos de mar que ele lhe recomendara devido aos trabalhos do engenho e queixava-se dos empregados, de sua saúde, da doença da filha, embora finalizasse dizendo que "o que me aflige é saber que passas mal, que tudo mais, para mim, nada vale, nada." 20

No entanto, essa marca individualista não lhe oculta uma alma generosa, sua fidelidade ao homem que lhe coubera amar, no qual não buscava defeitos e para quem nunca levantava censura - o que estava, aliás, de acordo com as espectativas da sociedade colonial sobre o papel a ser cumprido pela esposa na relação conjugal. Tal posição se revela em sentimentos expressados de várias maneiras, apresentando já a primeira carta recupera-

18 Carta de 8 de outubro de 1821.

19 Carta de 12 de maio de 1822.

20 Carta de 1823. 
da, essa afirmação: "Tu que, à custa de tua existência, queres o sossego e a lei mantida em seu vigor e a nação feliz, tu eras malvisto por esse punhado de harpias sujas." ${ }^{21} \mathrm{E}$, em outra missiva, enviada posteriormente, continuava declarando: "Oh! Luís, se tivessem seguido os teus conselhos, nada disso aconteceria. Portugal não perderia o Brasil e o Brasil não se perderia a si!" 22 E partia sempre em defesa do marido, até às ultimas conseqüências: "Desafronta-se ou, aliás, eu tiro-lhe a vida. Sou capaz, não duvides,"23 ameaçava ela ao mencionar Carlos Damasceno Rosado, inimigo de Luís Paulino, que procurava desacreditá-lo na sociedade baiana, durante sua ausência. $\mathrm{O}$ temor de que tais calúnias viessem a abalar a honra familiar poderia, também, agir como reforço dessa indignação.

A correspondência de Maria Bárbara dá, constantemente, margem a uma ampliação do foco de análise, chegando-se inclusive ao âmago da natureza humana, para desvendar a presença das emoções. E foram da pena dessa mulher de personalidade marcante e lúcida, que emanaram a maioria das cartas coletadas por Antonio Pinto da França. Recolhidas em maço dentre os pertences de Luís Paulino, devem ter viajado com ele de Lisboa à Bahia, da Bahia ao Rio e, de volta a Portugal, encontrando-se entre seus papéis depois que seu corpo foi lançado ao mar, em fevereiro de 1824. Fizeram, finalmente, parte do espólio entregue a seu filho mais velho, sendo levadas a Lisboa, onde passaram de geração em geração até chegarem à atualidade.

\section{Finalmente, as cartas}

Analisadas em seu aspecto estritamente formal, em seu estilo e linguagem, as Cartas Baianas, especialmente as escritas por Maria Bárba-

21 Primeira carta da coleção, $\mathrm{n} / \mathrm{d}$.

22 Carta de 24 de agosto de 1822 .

23 Carta de 20 de outubro, $\mathrm{n} / \mathrm{d}$. 
ra, fornecem rica informação sobre a visão de mundo de uma época e sobre uma figura feminina que, posta à prova por um conjunto de circunstâncias alheias a sua vontade, mostra-se tão claramente no simples ato de comunicar-se, escrevendo.

Já de início, as características de força e dominação inerentes ao personagem evidenciam-se na própria organização do texto: parágrafos compactos, densos, algumas vezes imensos, frases curtas, pontuação abundante, deixam transparecer a personalidade sólida da autora. E como que para suavizar essa apresentação um tanto rude e dura, o toque feminino lhe vem por meio do vocabulário muito vivo, da riqueza de detalhes, do caráter coloquial que perpassa, muitas vezes, a narrativa apaixonada: "Ouve mais e fica em espanto: o cobarde, o vil Rosado, logo que tu não lhe podias responder com a tua espada, espalhou por esta cidade que te desafiou e que tu não aceitaste o desafio." 24

Os sentimentos, opiniões e julgamentos aparecem nos apartes feitos em meio ao texto, como por exemplo: "que mundo patife!" 25 Ou ainda lança mão, com frequiência, das repetições: "Não se iludam aí: nada fazem com os brasileiros por força. Doçura e mais doçura, igualdade e mais igualdade." ${ }^{26}$ E queixando-se da falta de dinheiro: "Desde Janeiro para cá, para nada, nada, nada, nada Almeida dá dinheiro." ${ }^{27}$

Outros recursos dão também ao texto a marca da personalidade da autora: a riqueza da adjetivação: "o cobarde e vil Rosado, nossa malfadada Sabina;"28 e a utilização dos verbos: "rasgam-lhe o coração, carpo a tua pobre pátria, pois que se mordam. ${ }^{29}$ Auxiliando ainda o vigor do estilo aparece o uso reiterado de vocativos como força de expressão. Interrompendo a sequiência dos parágrafos, eles introduzem as emoções da autora sobre acontecimentos para ela catastróficos: "Que horror! Valha-nos Deus! (...) Deus nos acuda," 30 entre outros. No entanto, o que poderia parecer abuso estilístico, não chega a comprometer a clareza e a precisão do texto,

24 Carta de 21 de abril de 1822.

25 Carta de 21 de abril de 1822.

26 Carta de 12 de maio de 1822.

27 Carta de 21 de abril de 1822.

28 Cartas diversas.

29 Id.

30 Id. 
apoiado na correção e no domínio da linguagem.

São as cartas, por outro lado, subsídio para uma análise mais ampla que, desprendendo-se da autora e do estilo, pode levar ao exame mais aprofundado do perfil de uma mulher da região açucareira, no início do século XIX.

A primeira observação importante a esse respeito, refere-se ao papel social de uma dama da elite de Salvador que, mesmo após a morte do marido, continuou a participar das reuniões da sociedade baiana, onde ganhou fama de mulher enérgica, porém gentil. Wanderley Pinho conta sobre sua participação nas atividades mundanas da Corte durante o Império e a já mencionada descrição que dela fez o viajante Patroni. ${ }^{31} \mathrm{E}$, embora a época difícil e agitada em que foram escritas as cartas não permitisse atividades sociais mais intensas, percebe-se, pelas informações de que se dispõe, que as mulheres, ao menos as da elite, tinham acesso ao que se passava nos círculos dirigentes. No caso de Maria Bárbara, seus comentários demonstram um acompanhamento constante dos eventos políticos sobre os quais emitia opiniões e tomava posição. Em 15 de abril de 1822, por exemplo, manifestava-se a respeito da atuação do governo, prevendo a necessidade de uma ação imediata por parte dos deputados para evitar as desordens que ocorriam na Bahia, onde, a seu ver, não havia "tropas organizadas, bons comandantes ou oficialidade honesta."

E comentava que era preciso evitar que sucedesse à Bahia o que ocorria em Pernambuco "onde pretos e pardos (corja do diabo!) apedrejam e dão cacetada em todo lojista." ${ }^{32}$ Nesse período, na Bahia, como no Brasil, cor e posição social se confundiam. Ser branco era um privilégio construído na oposição à grande massa de negros e mestiços que compunha a população. E, nem mesmo os nascidos na terra que se consideravam brancos, escapavam da discriminação por parte dos europeus, ${ }^{33}$ dentre eles, os portugueses. A opinião de Maria Bárbara não parece, entretanto, consubstanciar-se numa atitude efetiva contra os negros e mestiços que para ela trabalhavam, e dos quais tolerava indisciplina e até desonestidade,

31 PINHO, apud FRANÇA, op. cit., p. 139-140.

32 Carta de 15 de abril de [182-].

33 REIS, J. A morte é uma festa. São Paulo: Companhia das Letras, 1991. p. 39. 
sem cogitar castigos mais violentos: "que negro péssimo é o tal feitor. Muito te sangrou e a combinação ia adiante, mas eu desfiz-lhe os arranjos dele e dos amigos." 34

De outra origem era a visão de Maria Bárbara a respeito da rivalidade entre portugueses e brasileiros; ela desejava a participação, rejeitava os radicalismos e aconselhava agir-se com doçura e igualdade. Aliás todas as suas posições a respeito de tais antagonismos estavam eivadas de um sentimento de amor ao Brasil e à Bahia: "Ah! Se eu via a pobre Bahia arrasada por capricho de Manoel Pedro [general das tropas na Bahia], ou de ambos, [Paula e Rosado], não sei que seria de mim..." ${ }^{35}$ Mas não consegue furtar-se ao discurso a que sua origem portuguesa a induzia: "Amo Portugal, gosto do Brasil e desejo o bem, pois não sou egoísta nem ambiciosa." ${ }^{36}$

Tal dualidade fazia, aliás, parte do pensamento dos portugueses radicados no Brasil, e inclusive de muitos brasileiros, para os quais a melhor solução para os conflitos existentes entre as duas nações seria manter unidos os dois reinos, sendo mantida a autonomia administrativa do Brasil. Mas, é preciso lembrar que tal moderação poderia não ser compartilhada por todos os conterrâneos (e conterrâneas) de Maria Bárbara, mais ligados talvez a posições exclusivamente nacionalistas, muito embora a Bahia tivesse sido um dos redutos de reação à independência.

É, no entanto, no campo econômico, como proprietária de engenho e sua administradora na ausência do marido, que Maria Bárbara entra para o rol de chefe de domicílio que não era incomum às mulheres do período colonial, responsáveis pela gestão de bens e negócios, na falta provisória ou definitiva do cônjuge. Trechos da carta enviada a Luís Paulino, em abril de 1822, dão conta das múltiplas tarefas que poderiam caber a uma proprietária de engenho, como acontecia com qualquer mulher que estivesse à testa de um empreendimento, naquela época:

34 Carta de 12 de maio de 1822.

35 Carta de 2 de março de 1822.

36 Carta de 13 de abril de 1822. 
...dei ao cirurgião que me assistiu duas caixas de açúcar; ao Simão Caldeira, quatro, e oito para pagar a carne-seca. Desde janeiro para cá, para nada, nada, nada, nada Almeida dá dinheiro. Pago vestuários de negros: noventas mantas, carretos, tudo, tudo. E o alambique não dá para tudo, pois a aguardente está muito barata, bem como o açúcar. ${ }^{37}$

\section{E numa carta de 15 de abril:}

...Almeida quer largar as assistências dos engenhos e, se tu com isso te não embaraças, da minha parte conto não lhe dar esse enfado na safra que vem, pois vejo que ele (é) forçado da amizade e nada mais, nada (...). Agora acrescem os juros das letras neste e no outro mês e ele ainda me deu na renda do primeiro mês menos cinqüenta mil réis. Enfim. A falta de assistência agora ao engenho não faz mal, pois eu sei regularme. ${ }^{38}$

Em outra correspondência evidenciam-se os problemas financeiros e as dificuldades encontradas pela discriminação feita às mulheres que cuidavam de negócios:

...A safra foi pequeníssima (...) mas fechamos dois mil e quatrocentos e sessenta pães (...). Têm-nos morrido muitos bois e, a não ser os 36 que comprei, pobre de mim. Este ano precisam-se muitos e cavalos, aliás, não se fará nada. Já te avisei que me desfaço de Almeida, pois comigo se tem portado muito mal. Recusou, enfim, firmas às letras (...). Mas podes estar descansado que Manuel Francisco de Souza firmou ambas. $^{39}$ 
E ainda: “...fico de acordo sobre dar as caixas que determinadas, mas vou fazer assinar as letras, pois no banco mão querem firmas de senhoras." ${ }^{40}$

O relato da recusa feita à firma de senhoras é tranqüilo, mais uma constatação do que uma queixa. Maria Bárbara não era, com certeza, uma feminista avant la lettre. Utilizava, apenas, estratégias que visavam resolver seus problemas mais imediatos. Cada conflito enfrentado lhe abria um campo de possibilidades onde ela se movia, utilizando as táticas de negociação que estavam a seu alcance. No mais, aceitava, simplesmente, as injunções que a situação lhe trazia, assumindo as mais variadas obrigações: supervisão da produção, colocação do produto, controle dos animais, levantamento de recursos, pagamento das dívidas, controle dos empregados, atendimento aos escravos. Como atestam suas cartas, melhorou o rebanho, supervisionou a produção da aguardente para evitar roubos e drenou o solo para evitar que o canavial apodrecesse na estação da chuva. ${ }^{41}$ As dificuldades enfrentadas nessas tarefas tinham de ser resolvidas da melhor maneira possível.

No Brasil, em que pese toda uma literatura baseada em esteriótipos sobre as diferentes condições de mulheres brancas, negras e mestiças, estudos mais recentes têm mostrado figuras femininas das mais diversas origens que, desde o início da colonização, estiveram à frente de negócios como engenhos, vendas e tabernas..$^{42}$ No caso das mulheres de famílias abastadas, o direito à propriedade era comum. Exercê-lo, todavia, era uma outra questão. Via de regra, as mulheres eram meeiras com seus maridos ou herdeiras de seus pais. No entanto, só exerciam esses direitos em caso de viuvez, falecimento dos progenitores ou ausência definitiva ou temporária dos maridos - como aconteceu com Maria Bárbara. Mas, de maneira geral, elas só tinham acesso à propriedade e seu controle tardiamente e as decisões de cada família determinavam o momento e a forma como ela dirigiria seus bens. Muito freqüentemente seu papel se resumia a de uma peça na engrenagem da transmissão dos bens familiares de uma geração masculina

40 Carta de 15 de abril de [182-].

41 SCHUMAER, S.; VIDAL, E. (Orgs.). Dicionário mulheres do Brasil: de 1500 até a atualidade. Rio de Janeiro: Zahar, 2000.

42 VAINFAS, R. (Dir.). Dicionário do Brasil Colonial: 1500-1808. Rio de Janeiro: Objetiva, 2000. p. 414-417. 
a outra; o que não impedia que se tornassem ricas e poderosas e que, assumindo todas as funções que a situação lhes trazia se tornassem, por vezes, chefes de domicílio. ${ }^{43}$

No caso de Maria Bárbara, sua ascendência no plano familiar a colocava numa posição de independência em relação aos filhos e, de certa forma, ao marido. Ninguém parecia opor qualquer resistência a suas iniciativas. Antônio Pinto da França lembra, no prefácio de sua coletânea, episódios em que ela tomou decisões financeiras e até políticas, sem a interferência dos filhos. Tal é o incidente de sua ida, em 1823, para o interior da província, (onde se aquartelavam os rebeldes ao governo da Bahia), contrariando a opinião de seu filho mais velho. ${ }^{44}$

Ao assumir todas essas responsabilidades, Maria Bárbara abriu mão da companhia do marido para permanecer à testa do engenho e tomava para si as preocupações com o futuro dos filhos e netos:

...não sei como poderei ir ao engenho, pois as chuvas têm sido horríveis e, em razão do pequenino Luís (o neto), hei de verme doida. Mas que será dos nossos filhos? Se desta vez não fico doida, grande milagre será. ${ }^{45}$

Em relação à filha casada, Maria Sabina, que considerava extremamente dominada pelo marido, sofria e lamentava-se:

Da nossa filha, há dias que não tenho notícias. Vou ali mandar (saber), mas com aquele homem (o genro) nada se faz. Contudo, trata bem a menina, mas eu não sei como poderei um dia separar-me dela. Eu não resistirei a um tal golpe, mas será preciso. ${ }^{46}$

Maria Sabina, dócil e submissa, faz contraponto à mulher forte representada pela mãe, mostrando a outra face da condição feminina no

43 METCALF, A. Mulheres e propriedade: filhas, esposas e viúvas em Santana de Parnaíba no século XVIII. Revista da SBPH, São Paulo, n. 5, p. 19-30, 1989/1990.

44 FRANÇA, op. cit., prefácio. p. XV.

45 Carta de 6 de julho de 1822.

46 Carta de 12 de maio de 1822. 
período. Na única carta de sua autoria, constante dos documentos, ela se dirige ao pai em estilo correto, porém apagado e conformista, em que entremeia protestos de felicidade conjugal com receio sobre o futuro dos homens da família. A essa mulher do tipo submissa, acrescenta-se um terceiro perfil, o da portuguesa Maria Libória Máxima Guilhermina, sogra de Luís Paulino que, em duas cartas dirigidas ao genro, mostra uma postura contida de dama provinciana, envolta em uma realidade alheia à que vivia a filha distante.

Por fim, dentre outra correspondência de menor interesse, é importante relacionar as que envolvem as posições dos homens da família, frente à liderança assumida por Maria Bárbara. Dos dois filhos homens, apenas o mais novo, Luís, demonstrava maior envolvimento nos negócios do engenho, prestando auxílio às tarefas de que sua mãe se incumbia. Mas à medida que o tempo passava, que ambos se preocupavam cada vez mais com os problemas políticos da província e suas questões pessoais, solicitando freqüentemente ao pai, auxílio em suas dificuldades. Esse, tanto quanto eles, parecia aceitar sem questionamento o papel assumido pela mulher.

As poucas cartas que restaram do chefe da família são anteriores às décadas em análise e revelam um temperamento muito mais comedido que o da esposa. Seu estilo é mais leve e mundano. O carinho que demonstrava por parentes e amigos e a solicitude para com a esposa e sua saúde, fazem lembrar o cavalheirismo de um homem da sociedade. Por esse motivo, sua atitude obstinada no episódio da Constituinte, suportando insultos e pressões, parece um tanto surpreendente para o leitor que não tem acesso a sua correspondência da época, conquanto se saiba ter sido ele um homem de princípios. E, embora houvesse empreendido a instalação do engenho Aramaré, em sociedade com os cunhados, essa iniciativa parecia ser muito mais o usufruir de um direito que sua posição lhe facultava, e talvez a preocupação de garantir financeiramente um futuro remoto, do que um empreendimento em que se empenhasse com interesse real.

Já a correspondência de Maria Bárbara, crivada dos problemas da administração do engenho, demonstra um apego muito maior às preocupações materiais. Talvez esse casamento fosse uma daquelas surpreendentes uniões que reunem o espírito sonhador à iniciativa prática, o poeta e a empresária. 


\section{Considerações finais}

Em obra recente, a historiadora Natalie Zemon Davis traçou o perfil de três mulheres do século XVII, recuperando a condição feminina e o cenário cultural europeu da época. Para tanto, utilizou os escritos pessoais e as cartas dessas mulheres, no intuito de compreender suas trajetórias pessoais e o mundo que viveram. ${ }^{47}$ A situação das heroínas de Davis podem servir de parâmetro para a análise da vida e dos escritos de Maria Bárbara, mesmo que esses estejam limitados a uma correspondência restrita a um determinado período. Diferentemente daquelas, ela foi representativa de uma elite em certa época e lugar. Foi, também, uma das mulheres que tiveram que assumir as funções de proprietárias e chefes de domicílio, mesmo que isso não fosse a regra geral.

Permanece, assim, a consideração inicial de que as Cartas Baianas são uma excelente fonte para uma reconstituição histórica, pela leitura que elas facultam sobre episódios da sociedade baiana no período da independência. Fornecem e fornecerão subsídios para estudar-se um grupo significativo de mulheres no período colonial brasileiro.

Não se pode, ainda, esquecer que Maria Bárbara, sendo portuguesa, muitas vezes sentia e agia como tal, em que pese seu amor pelo Brasil e pela Bahia. Uma posição que não era incomum no Brasil às vésperas da independência quando portugueses, e até brasileiros, se debatiam numa fidelidade dual às duas pátrias, num verdadeiro conflito de identidade.

Por tudo isso, talvez, nas entrelinhas e nas referências que a ela fazem outras pessoas e autores, pode-se ao menos perceber que Maria Bárbara era aceita e considerada no meio em que vivia, e assim permaneceu, mesmo depois da morte do marido. Assim, o perfil dessa mulher parece ser o de uma pessoa de exceção, sobretudo se considerarmos as circunstâncias do momento que as cartas retratam. Ela preenchia todas as condições exigidas em seu meio social e seu contexto familiar. Numa sociedade em que muitas mulheres eram tidas como desonestas e de mau comportamento por atitudes mais livres e menos comprometidas com as normas vigentes, Maria

47 DAVIS, N. Z. Nas margens: três mulheres do século XVII. São Paulo: Companhia das Letras, 1997 
Bárbara cumpria o modelo ideal de procriação legítima, zelo conjugal e costumes virtuosos que, justamente por serem raros, eram extremamente valorizados. ${ }^{48}$

Por muitas razões, a Maria Bárbara do século XIX, num Brasil longínquo, não se via tanto às margens da sociedade como suas companheiras do início do mundo moderno. Sua vida foi menos atribulada, o que não impede de a vermos como alguém que enfrentou corajosamente seus desafios. A sociedade brasileira de seu tempo, apesar de não contar com um número significativo de mulheres do teor de uma Maria Bárbara, com sua cultura, sua consciência política e social, sua capacidade de iniciativa, estava ao menos preparada para acolhê-la e até admirá-la.

E admiração é o que suscita esse lamento final de uma mulher dividida entre duas pátrias e inúmeros deveres:

Muito tenho falado e talvez dito algumas loucuras a respeito de política. Se assim for, desculpa-me, mas eu vou já perdendo algum lume da razão que tinha. E acabo por dizer-te que até o ano de 1824 queria achar-me em Portugal, queria acabar meus dias na minha pátria, beijar ainda a mão querida de uma mãe e abraçar os irmãos que me restam. Mas não quero deixar os meus sem pão e, para segurar isso é forçoso sacrifício. Adeus, adeus, meu Luís, adeus. ${ }^{49}$

48 FARIA, S. C. A colonia em movimento: fortuna e família no cotidiano colonial. Rio de Janeiro: Nova Fronteira, 1998. p. 95.

49 Carta de 24 de agosto de 1822. 


\section{Referências}

CAMARGO, M. R. Cartas adolescentes. Uma leitura e modos de ser... In: Refúgios do eu: educação, história e escritos autobiográficos. Florianópolis: Mulheres, 2000.

CHARTIER, R. A história hoje: dúvidas e propostas. Estudos Históricos, Rio de Janeiro, p. 97-113, 1994.

COSTA, E. V. da. Da Monarquia à República: momentos decisivos. São Paulo: Brasiliense, 1985.

DAVIS, N. Z. Nas margens: três mulheres do século XVII. São Paulo: Companhia das Letras, 1997.

DEL PRIORE, M. (Org.). História das mulheres no Brasil. São Paulo: Contexto, 1997.p. 401-442.

DIAS, C. G. P. um olhasr sobre o livro Nas margens de Natalie Zemon Davis: em busca de uma reflexão a partir do gênero biográfico. Histórica, Porto Alegre, n. 5, p. 103-110, 2001.

FARIA, S. C. A colônia em movimento: fortuna e família no cotidiano colonial. Rio de Janeiro: Nova Fronteira, 1998.

FRANÇA, A. O. P. da. Cartas Baianas. 1821-1824. São Paulo: Companhia Editora Nacional, 1980.

HISTÓRIA das mulheres: o século XIX. Porto: Afrontamento, 1991. v. 4, p. 171-197.

METCALF, A. Mulheres e propriedade: filhas, esposas e viúvas em santana de Parnaíba no século XVIII. Revista da SBPH, São Paulo, n. 5, p. 19-30, 1989/1990.

REIS, J. A morte é uma festa. São Paulo: Companhia das Letras, 1991.

REVEL, J. (Org.). Jogos de escalas. A experiência da microanálise. São Paulo: Fundação Getúlio Vargas, 1998.

SCHMIDT, B. B. Construindo biografias... historiadores e jornalistas: aproximações e afastamentos. Estudos Históricos, Rio de Janeiro, p. 15, 1997. 
SCHUMAER, S.; VIDAL, E. (Orgs.). Dicionário mulheres do Brasil: 1500 até a atualidade. Rio de Janeiro: Zahar, 2000.

VAINFAS, R. (Dir.). Dicionário do Brasil Colonial: 1500-1808. Rio de Janeiro: Objetiva, 2000.

ZELDIN, T. História pessoal e história das emoções. História: Questões \& Debates, ano 12, n. 22/23, p. 33, jun./dez. 1991.

ZELDIN, T. Uma história íntima da humanidade. Rio de Janeiro: Record, 1999. 